SHS Web of Conferences 2, 00019 (2012)

DOI: $10.1051 /$ shsconf/20120200019

(C) Owned by the authors, published by EDP Sciences, 2012

\title{
The impact of dental restorations' quality on caries risk
}

\author{
I. Maldupa, A. Brinkmane, A. Mihailova and I. Rendeniece \\ Rīga Stradiņš University, Latvia
}

\begin{abstract}
The purpose of this study was to evaluate how the quality of government funded restorations can impact caries prevalence. After randomisation, One hundred thirty five (135) 12-13-year-old children were examined in the Gulbene municipality of Latvia and 175 restorations placed in premolars or second molars were evaluated. It was concluded that the quality of restorations made by publicly funded dentistry is low, which could be a reason for secondary caries and other complications and results in greater expenses in the future.
\end{abstract}

Key words: dental restorations quality, caries risk

Dental research has to concentrate on prevention and minimal intervention (Söderholm et al., 1998); however, restorations are still required for caries at the dentinal level. To lower the risk of caries, restorations should be placed accurately (Söderholm et al., 1998). As the highest risk for recurrent caries is in gingival area (Söderholm et al., 1998; Sunnegårdh-Grönberg et al., 2009), a high quality of restorations in the gingival margin is significant to ensuring appropriate oral hygiene (Hewlett et al., 1993; Goldberg, 1990).

There isn't sufficient evidence to claim whether amalgam or composite fillings are better (Opdam et al.,2011) and no studies have been made comparing cheap tooth coloured restorations with cheap amalgams, which could be a useful finding for selecting materials for government financed dental treatment. There have been no studies made in Latvia about the quality of restorations, but there is sufficient evidence of high caries prevalence in Latvia (Berzina et al., 2003; Gudkina et al., 2008; Henkuzena et al., 2004; Rence-Bambite et al., 2003). As dental treatment is free of charge for children up to 18 years of age in Latvia, it is important that there is no need for the government to pay for the replacement of the same restorations many times (Sharif et al., 2010).

The purpose of this study was to evaluate government financed restorations in one region of Latvia and to estimate how the quality of fillings can impact the risk of recurrent caries.

\section{Materials and methods}

\section{Study design and location}

A cross-sectional epidemiological study was conducted in September of 2009 in all eighteen schools in the Gulbene municipality of Latvia. One hundred thirty five (135) adolescents aged 12-13 were interviewed and examined. This corresponds to $34 \%$ of $12-13$-year-old schoolchildren in Gulbene.

The Gulbene municipality (a Latvian administrative division) has an area of $1,876.1 \mathrm{~km}^{2}-$ in 2009 there were 25,546 inhabitants and the population density was 13.62 inhabitants $/ \mathrm{km}^{2}$. The city of Gulbene (considered an urban area) has an area of $11.898 \mathrm{~km}^{2}$ and the population density in 2009 was 785 inhabitants $/ \mathrm{km}^{2}$. Gulbene is located $181 \mathrm{~km}$ from Riga, the capital of Latvia, and $60 \mathrm{~km}$ from the eastern border of the country. The average monthly salary in this region was EUR 247.8 (compared to the Latvian average of EUR 322.7), and the unemployment rate was $11.8 \%$ in 2009. Water fluoridation has

This is an Open Access article distributed under the terms of the Creative Commons Attribution License 2.0, which permits unrestricted use, distribution, and reproduction in any medium, provided the original work is properly cited. 


\section{SHS Web of Conferences}

never been introduced and the natural level of fluoride in the water is $0.2-0.3 \mathrm{mg} / \mathrm{l}$. There is one dentist to every 3,194 inhabitants and one dental hygienist to every 25,546 inhabitants in Gulbene, while in Latvia overall there is one dentist to every 1,514 inhabitants and one dental hygienist to every 10,926 inhabitants. Additionally, to provide accessibility to dental care there are two mobile dental offices working in schools in rural areas in Latvia.

\section{Data collection}

A sample of 12-13-year-old students was selected by simple randomisation. The sample size was calculated to be $30 \%$ of the 12-13 year-old population of the Gulbene municipality and by adding potential loss (30\%), a total of 188 students were selected using the computer program Microsoft Visual FoxPro. According to codes given to every child, explanatory letters and agreements were sent to their parents. Informed consent was received from 138 parents $(73.4 \%)$, but one couple emigrated to another country and another two were absent on the day of the examination, leaving a final sample of 135 children, which is $34 \%$ of the $12-13$ year old population in the Gulbene region.

Examinations took place in schools using a mobile light unit, dental mirror, and a dental probe that was used only for the removal of loose debris and plaque. No probing was performed (Pitts, 2001). Cotton wool was used for moisture control (Pitts, 2009). No radiographs were taken.

Caries was measured using the criteria of the International Caries Detection and Assessment System (ICDAS) (Topping et al., 2009). To record caries status, the DMFT index was used. ICDAS caries codes ranging from 3 to 6 were classified as damaged (D) (Mendes et al., 2010). The level of plaque was measured using the Silness - Löe index (Silness, Löe, 1964). Caries risk was assessed using the computer program "Cariogram”, developed at Malmö University in Sweden (Bratthall et al., 2005). The information necessary to assess caries risk was gained in the form of an interview.

The FDI World Dental Federation clinical criteria, published first in 2008 as a web-based training and calibrating tool called $e$-calib, were used to assess quality of restorations (Hickel et al., 2010). Quality assessment included 4 esthetical parameters, 6 functional parameters and 6 biological parameters (Hickel et al., 2010). As no radiographs were used, the corresponding functional parameter wasn't assessed. Information gained about patient satisfaction and post-operative sensitivity wasn't reliable, so two more parameters were excluded, leaving 4 esthetical parameters, 2 functional parameters and 5 biological parameters (Table 1), where codes 1 to 3 mean the restoration is acceptable (no intervention required), 4 means restoration is clinically unsatisfactory and should be repaired and 5 means the filling is clinically poor and should be replaced (Hickel et al., 2010). To exclude individual factors, if the child had more than 3 restorations only three were randomly selected and evaluated. That corresponded to 175 restorations.

The individual ratio of restorations' quality (IRRQ) was calculated as the number of an individual's satisfactory restorations divided by the total number of restorations present (Brukiene et al., 2005).

This study was approved by the Ethics Committee of the Riga Stradins University. Data was collected only with written informed consent.

\section{Statistical analysis}

The statistical analysis was performed using the Statistical Package for Social Sciences (SPSS, version 16.0 for Windows). The acquired data was checked for normal distribution using the KolmogorovSmirnov test. The statistical analysis included descriptive statistics and non-parametrical statistical tests. The Mann-Whitney U test was used to test the significance of the ranked data for two independent groups, but for more than two groups the Kruskal-Wallis test was used. All significant differences were detected at a $95 \%$ confidence level $(\mathrm{p}<0.05)$. 
Int. Conf. SOCIETY. HEALTH. WELFARE; Congr. of Rehabilitation Doctors of Latvia

Table 1. The modified FDI World Dental Federation clinical criteria for evaluation of restorations' quality.

\begin{tabular}{|c|c|c|}
\hline & Properties & Criteria \\
\hline \multirow{4}{*}{ 胥 } & $\begin{array}{l}\text { Surface } \\
\text { luster }\end{array}$ & $\begin{array}{l}\text { 1. Luster comparable to enamel. } \\
\text { 2. Slightly dull, not noticeable from speaking distance. } \\
\text { Some isolated pores. } \\
\text { 3. Dull surface but acceptable if covered with film of saliva. Multiple pores } \\
\text { on more than one third of the surface. } \\
\text { 4. Rough surface, cannot be masked by saliva film, simple polishing is not } \\
\text { sufficient. Further intervention necessary. Voids. } \\
\text { 5. Quite rough, unacceptable plaque retentive surface. }\end{array}$ \\
\hline & $\begin{array}{l}\text { Surface and } \\
\text { marginal } \\
\text { staining }\end{array}$ & $\begin{array}{l}\text { 1. No surface staining. No marginal staining. } \\
\text { 2. Minor surface staining, easily removable. Minor marginal staining, easily } \\
\text { removable. } \\
\text { 3. Moderate surface staining, also present on other teeth, not aesthetically } \\
\text { unacceptable. Moderate marginal staining, not aesthetically unacceptable. } \\
\text { 4. Surface staining present on the restoration and is unacceptable; major } \\
\text { intervention necessary for improvement. Pronounced marginal staining; major } \\
\text { intervention necessary for improvement. } \\
\text { 5. Severe surface staining and/or subsurface staining (generalized or localized, } \\
\text { not accessible for intervention). Deep marginal staining, not accessible for } \\
\text { intervention }\end{array}$ \\
\hline & $\begin{array}{l}\text { Colour } \\
\text { match and } \\
\text { translucency }\end{array}$ & $\begin{array}{l}\text { 1. Good colour match. No difference in shade and translucency. } \\
\text { 2. Minor deviations. } \\
\text { 3. Clear deviation but acceptable. Does not affect aesthetics: more opaque, more } \\
\text { translucent, darker, brighter. } \\
\text { 4. (Localised) clinically unsatisfactory but can be corrected by repair: too opaque, } \\
\text { too translucent, too dark, too bright. } \\
\text { 5. Unacceptable. Replacement necessary. }\end{array}$ \\
\hline & $\begin{array}{l}\text { Esthetic } \\
\text { anatomical } \\
\text { form }\end{array}$ & $\begin{array}{l}\text { 1. Form is (almost) ideal. } \\
\text { 2. Form is only slightly affected. } \\
\text { 3. Form differs but is not aesthetically displeasing. } \\
\text { 4. Form is affected and unacceptable aesthetically. Intervention (correction) } \\
\text { necessary. } \\
\text { 5. Form is completely unsatisfactory and/or lost. Repair not } \\
\text { feasible/reasonable, replacement needed. }\end{array}$ \\
\hline \multirow{2}{*}{ 尊 } & $\begin{array}{l}\text { Fracture of } \\
\text { material and } \\
\text { retention }\end{array}$ & $\begin{array}{l}\text { 1. No fractures/cracks. } \\
\text { 2. Small hairline crack. } \\
\text { 3. Two or more or larger hairline cracks and/or material chip fracture (not } \\
\text { affecting the marginal integrity or proximal contact). } \\
\text { 4. Material chip fracture which damage marginal quality or proximal contacts; } \\
\text { Bulk fractures w/o or with partial loss (less than half of the rest.). } \\
\text { 5. (Partial or complete) loss of restoration. }\end{array}$ \\
\hline & $\begin{array}{l}\text { Marginal } \\
\text { adaptation }\end{array}$ & $\begin{array}{l}\text { 1. Harmonious outline, no gaps, no white lines } \\
\text { 2. Marginal gap }(<150 \mu \mathrm{m}) \text {, white lines. Small marginal fracture removable by } \\
\text { polishing. Slight ditching, slight step/flashes, minor irregularities. } \\
\text { 3. Gap }<250 \mu \mathrm{m} \text { not removable. Several small marginal fractures. Major } \\
\text { Irregularities, ditching or flashes, steps. } \\
\text { 4. Gap }>250 \mu \mathrm{m} \text { or dentine/base exposed. Severe ditching or marginal fractures. }\end{array}$ \\
\hline
\end{tabular}




\section{SHS Web of Conferences}

Table 1. Continued.

\begin{tabular}{|c|c|c|}
\hline & & $\begin{array}{l}\text { Larger irregularities or steps (repair necessary). } \\
\text { 5. Filling (complete or partial) is loose but in situ. }\end{array}$ \\
\hline \multirow{5}{*}{ 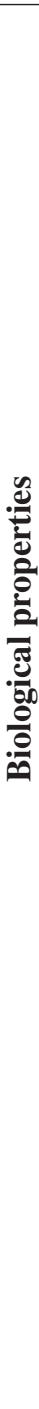 } & $\begin{array}{l}\text { Recurrence } \\
\text { of caries }\end{array}$ & $\begin{array}{l}\text { 1. No secondary or primary caries. } \\
\text { 2. Very small and localized demineralization. } \\
\text { 3. Larger areas of demineralisation. Only preventive measures necessary (dentine } \\
\text { not exposed). } \\
\text { 4. Caries with cavitation or suspected undermining caries. Localized and } \\
\text { accessible and can be repaired. } \\
\text { 5. Deep caries or exposed dentine that is not accessible for repair of restoration. }\end{array}$ \\
\hline & $\begin{array}{l}\text { Tooth } \\
\text { integrity } \\
\text { (enamel } \\
\text { cracks, tooth } \\
\text { fractures) }\end{array}$ & $\begin{array}{l}\text { 1. Complete integrity. } \\
\text { 2. Small marginal enamel split }(<150 \mu \mathrm{m}) \text {. Hairline crack in enamel }(<150 \mu \mathrm{m}) \text {. } \\
\text { Marginal enamel split }<250 \mu \mathrm{m} \text {. Crack }<250 \mu \mathrm{m} \text {; Enamel chipping. Multi. } \\
\text { cracks } \\
\text { 4. Major marginal enamel split (gap }>250 \mu \mathrm{m} \text { or dentine or base exposed). Large } \\
\text { cracks }>250 \mu \mathrm{m} \text { (probe penetrates). Large enamel chipping or wall fracture } \\
\text { 5. Cusp or tooth fracture. }\end{array}$ \\
\hline & $\begin{array}{l}\text { Periodontal } \\
\text { response }\end{array}$ & $\begin{array}{l}\text { 1. No plaque, no inflammation, no pockets. } \\
\text { 2. Little plaque, no inflammation (gingivitis), no pocket development } \\
\text { 3. Difference up to one grade in severity of PBI compared to baseline and in } \\
\text { comparison to control tooth. } \\
\text { 4. Difference of more than one grade of PBI worsening in comparison to control } \\
\text { tooth or increase in pocket depth }>1 \mathrm{~mm} \text { requiring intervention. } \\
\text { 5. Severe/acute gingivitis or periodontitis. }\end{array}$ \\
\hline & $\begin{array}{l}\text { Adjacent } \\
\text { mucosa }\end{array}$ & $\begin{array}{l}\text { 1. Healthy mucosa adjacent to restoration. } \\
\text { 2. Healthy after minor removal of mechanical irritations (sharp edges etc.). } \\
\text { 3. Alteration of mucosa but no suspicion of causal relationship with filling } \\
\text { material. } \\
\text { 4. Suspected mild allergic, lichenoid or toxicological reaction. } \\
\text { 5. Suspected severe allergic, lichenoid or toxicological reaction. }\end{array}$ \\
\hline & $\begin{array}{l}\text { Oral and } \\
\text { general } \\
\text { health }\end{array}$ & $\begin{array}{l}\text { 1. No oral or general symptoms. } \\
\text { 2. Minor transient symptoms of short duration (of known or unknown origin) } \\
\text { local or generalized. } \\
\text { 3. Transient symptoms, local and/or general. } \\
\text { 4. Persisting local or general symptoms of oral contact stomatitis or lichen planus } \\
\text { or allergic reactions (or remitting). Intervention necessary but no replacement. } \\
\text { 5. Acute/severe local and/or general symptoms. }\end{array}$ \\
\hline
\end{tabular}

\section{Results}

Sixty nine (69) females and sixty seven (67) males were examined, respectively $49.3 \%$ and $50.7 \%$ of the total sample size. The average age was 12.8 years. The caries prevalence was $89 \%$, the average (SD) DMFT was 5.61 (4.22). Only $33.8 \%$ of schoolchildren brushed their teeth more than one time per day. The average (SD) Silness-Löe plaque index value was 1.78 (0.67). Caries risk assessment shows that $55.6 \%$ of children were in the very high caries risk group, $25.2 \%$ in the high risk group, $10.4 \%$ in the intermediate group, $6.7 \%$ in the low group and $2.2 \%$ in the very low group.

Eighty three $(83 ; 61.76 \%)$ students had at least one filling and the prevalence of recurrent caries was $41.20 \%$. In total, students had 293 restorations, from which 118 had secondary caries. Considering individual ratio of restorations quality (IRRQ), 28 (33.30\%) pupils had IRRQ $=100 \%$ (all restorations were satisfactory, no intervention required), but for $12(14.45 \%)$ schoolchildren all fillings required 
Int. Conf. SOCIETY. HEALTH. WELFARE; Congr. of Rehabilitation Doctors of Latvia

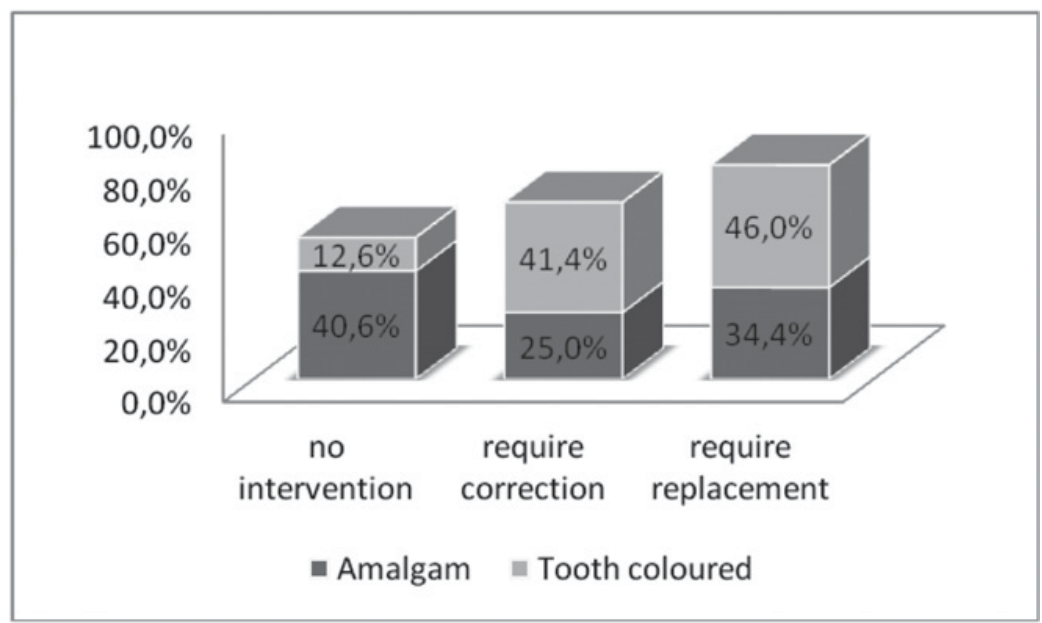

Figure 1. Correction and replacement needs for amalgam and tooth coloured restorations.

changing (IRRQ $=0 \%$ ). To evaluate new restorations (no more than 2 years in the mouth) restorations in premolars and second molars were additionally counted. In total children had 70 such restorations, from which 20 (28.6\%) had secondary caries.

One hundred seventy five (175) restorations were evaluated (65 (37\%) amalgam and $110(63 \%)$ tooth coloured), and 74 (42\%) of these fillings were evaluated as unsatisfactory and should be changed, $61(35 \%)$ require correction, while only $40(23 \%)$ restorations were evaluated as satisfactory. It was different for amalgam and for tooth coloured restorations (Figure 1).

Caries and irritation of periodontal tissues are frequent reasons for restorations to require replacement, but anatomical form, surface smoothness, colour and surface and marginal pigmentation are reasons for correction needs (Figure 2).

In terms of gender there were no statistically significant differences in the number of fillings, caries rate, the prevalence of caries and recurrent caries and the quality of dental restorations, but there was a statistically significant difference between genders on the Silness-Löe index $(p=0.009)$ and the frequency of tooth-brushing ( $p<0.001)$. Most girls $(61 \%)$ brushed their teeth more than once per day, while only $29 \%$ of boys did the same, and all girls brushed their teeth at least once per week but $8 \%$ boys brushed less than once per week.

There were 95 (70\%) students living in rural areas and 40 (30\%) from Gulbene city schools. With regards to urban and rural areas, there were no statistically significant differences in Silness-Löe index or in the frequency of tooth-brushing, but it was found that in rural areas there is a significantly higher number of fillings $(p=0.044)$, as well a higher caries rate $(p<0.001)$ and prevalence of recurrent caries $(p=0.007)$.

The prevalence of recurrent caries is influenced by caries risk $(p=0.001)$, but no statistically significant influence was found for the Silness-Löe index and the frequency of tooth-brushing.

\section{Discussion}

The current study showed that despite the fact that caries prevalence was $89 \%$ for 12-13-year-old children in Gulbene municipality, the prevalence of fillings was only $62 \%$. The quality of these restorations is low, as $40 \%$ of all restorations had recurrent caries. The seriousness of the dental caries problem in Gulbene municipality is shown also by the number of restorations placed in premolars and second molars $(70 ; 24 \%$ of all restorations), as these teeth in 12-13-year-olds hadn't been erupted 


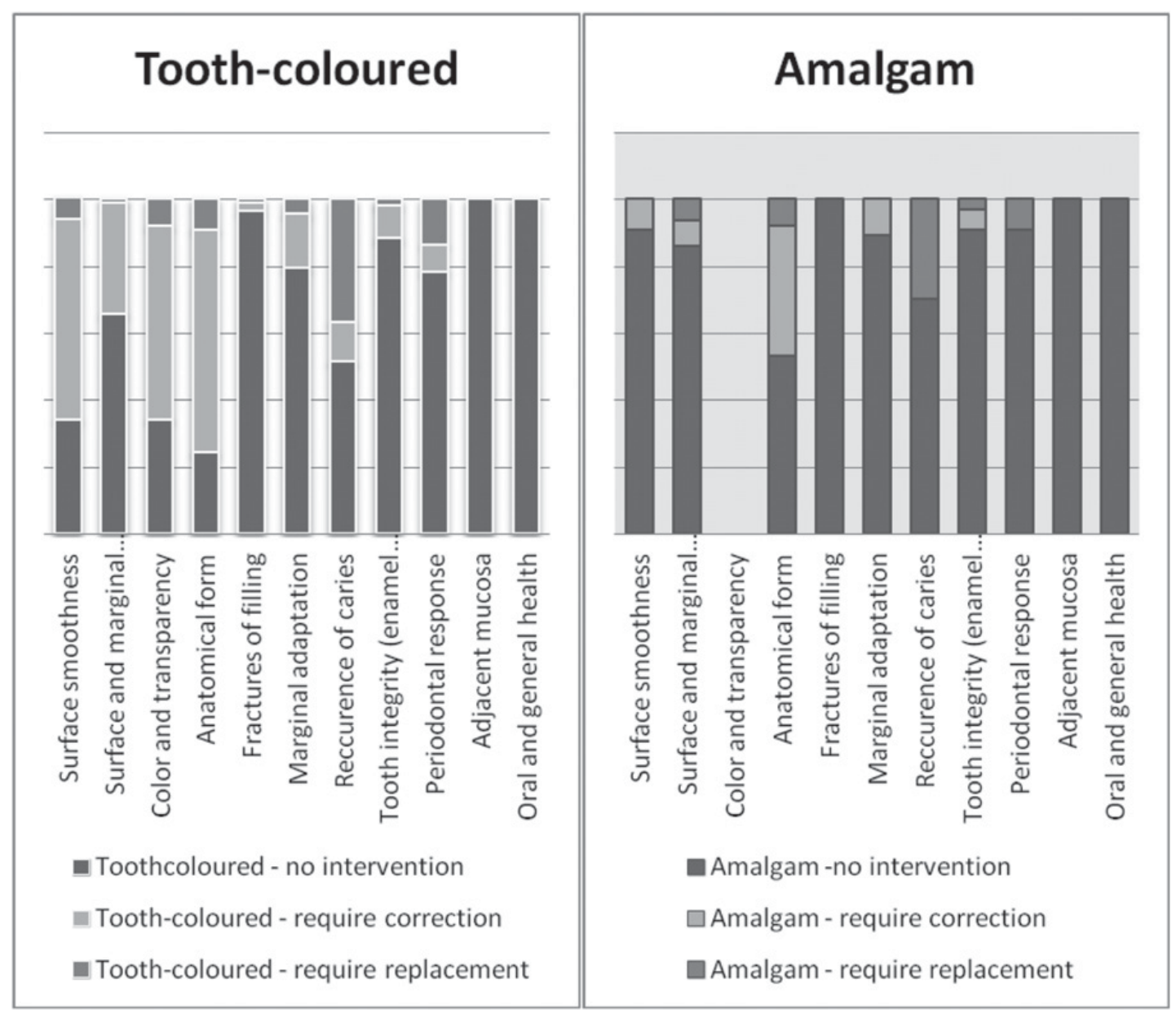

Figure 2. Reasons for tooth-coloured and amalgam restorations to require correction or replacement.

for more than 2 years. An even more surprising fact is that almost one-third of them already need replacement because of caries.

There are different results for the longevity of dental restorations, but most of the authors predict 6 to 10 years to be an average lifetime for composites (Kubo, 2011; Sunnegårdh-Grönberg, 2009).

When comparing different materials for restorations in the current study, amalgam displayed better results. The same findings had been apparent in other studies (Kirkevang et al., 2009; Van Nieuwenhuysen et al., 2003; Burke et al., 2005), however, in a recent review which compared composite and amalgam, the authors concluded that the results of such studies couldn't be evaluated equipollently because they are biased (Opdam et al., 2011). And some studies have shown that if a material had been used following all instructions then composites can last for more than 10 years (Kubo, 2011), but most tooth coloured restorations in the Gulbene region were made from glass ionomer cement. In last decade, ionomers have experienced many improvements and although the fluoride realised effect is not clear (Ozer et al., 1995; Papagiannoulis et al., 2002), different physical properties have been improved (Scholtanuse et al., 2007). However, recent findings showed that using Fuji IX for class two restorations results in a loss of the material in proximal areas, and what is important is that these defects of material 


\section{Int. Conf. SOCIETY. HEALTH. WELFARE; Congr. of Rehabilitation Doctors of Latvia}

were similar to those in carious dentin. It is thought that the bacteria of dental plaque causes these breakdowns of material (Scholtanuse et al., 2007). That means that a lack of oral hygiene could be a reason for early recurrent caries around tooth coloured restorations made in Gulbene.

Although in other studies oral hygiene has been found as a determinant of recurrent caries (Goldberg, 1990), this didn't occur in the current study - but there was found to be a coherency between secondary caries and caries risk, which is supported by other researchers (Kubo, 2011; SunnegårdhGrönberg et al., 2009). There was a strong relationships between gender and tooth brushing habits, but again no correlations between gender and the number of filled teeth or recurrent caries. However, in a similar study in Lithuania it was found that girls had more restorations; correspondingly, more unacceptable fillings were found for girls, but no significant differences regarding the individual ratio of restorations quality (Brukiene et al., 2005). Similar to previous mentioned Lithuanian study (Brukiene et al., 2005) we found that there are more fillings and higher prevalence of recurrent caries in rural areas.

Marginal caries is one of the most frequent reasons mentioned in literature for restorations being evaluated as unsatisfactory (Kroeze et al., 1990) and more than $20 \%$ of tooth coloured restorations in the study had marginal defects, but as a defective margin alone doesn't mean there is caries in dentine (Kidd et al., 1990), most of them required only correction, which could be an effective treatment (Scharif et al., 2010). However, only half of tooth coloured and $70 \%$ of amalgam restorations had no caries, which is why caries was the most important reason for restorations being evaluated as unsatisfactory. The same findings have been observed in other studies (Kidd et al., 1990; Kroeze et al., 1990; Kirkevang et al., 2009, Sarrett, 2005; Opdam et al., 2004), but the second main reason mentioned in literature is the fracture of restorations (Sarrett, 2005; Opdam et al., 2004). Periodontal changes have been found in the current study as the reason for $14 \%$ of tooth coloured and $9 \%$ of amalgams requiring replacement. That means there is lack of equipment or operators' abilities to make smooth gingival margin and contact points.

In analysing the acquired data the question about quality raises. There isn't one definition what a dental restoration should look like, but there are some points which should be observed - a cavity should have well-defined margins with perfectly adapted restoration and accurate reproduction of anatomic form of the tooth (Söderholm et al., 1998). Of course, recurrent caries as primary caries is caused by acids produced from plaque bacteria, but, if the restoration is rough, with marginal defects, it can create additional retentive places for plaque accumulation (Söderholm et al., 1998). Although glass ionomers have been improved it doesn't mean that materials used in Gulbene were the same quality, as $66 \%$ of tooth coloured restorations had rough surface and $20 \%$ had marginal defects. A similar situation had been found in England and Wales, where authors suggested that the operator effect is also important (Burke et al., 2005).

There are eight female dentists working in this area. From literature there is evidence that female dentists more often recommend topical fluorides for home use, and they more often use preventive treatment for early stages of caries (Riley III et al., 2011), but this couldn't be referred to in the Gulbene region as number of dentists is so small (one per more than 3,000 inhabitants) in a high caries risk population. And so the quality of dentists' work has been effected by a lack of time. Another reason could be a lack of financing that leads up to cheaper materials, shorter time for visits, disuse of a rubber dam and the usage of amalgam without bonding (although there isn't strong evidence about the advantages of bonded amalgam) (Federowicz et al., 2009).

The proportion of amalgam and tooth coloured restorations shows that the latter are becoming more popular, but the quality of these is lower, therefore curriculum of dental education should be changed with the target of improving skills for future dentists (Anusavice et al., 2001).

Studies where quality should be evaluated are never equipollent as there always exist subjective factors. It was found that many dentists consider restorations unacceptable even when they have no caries (Elderton, 1990), in some situations there are difficulties in distinguishing recurrent caries from residual or arrested caries (Kidd, 1990). Therefore, for the first time in Latvia, the FDI World 


\section{SHS Web of Conferences}

Dental Federation clinical criteria were used for the evaluation of dental restorations' quality, but a lack of radiographic examination (Hewlett, 1993) should be considered a limit of the current study.

\section{Conclusions}

It can be concluded that the quality of government funded restorations, especially tooth-coloured, for children is low. As tooth-coloured are becoming more popular, dental students' education should be changed. As there is a high caries risk for children in Gulbene, it is necessary to improve oral hygiene habits, reduce fermentable carbohydrates and promote remineralisation therapy to lower the risk of recurrent caries. Restorations with low quality could be a reason for recurrent caries and further replacement of restorations, which is why executive organisations should consider a new financing model to promote better quality when treating primary caries.

The study was financially supported by the European Social Fund. Support from The Centre of Dentistry and Maxillofacial Surgery of Pauls Stradins Clinical University Hospital is gratefully acknowledged and the authors wish to express appreciation to the teachers and medical personnel of all eighteen schools in Gulbene municipality. The authors declare they have no competing interests.

\section{References}

[1] Anusavice, K.J., Benn, D.K. (2001) Time to change state and regional dental licensure board exams in response to evidence from caries research? CROMB, 12, p. 368-372. DOI: $10.1177 / 10454411010120050101$.

[2] Berzina, S., Care, R. (2003) Dental health in 11 and 13 year old children in Latvia. Stomatologija, Baltic Dental and Maxillofacial Journal, 5, p. 62-64.

[3] Brathall, D., Hänsel-Peterson, G. (2005) Cariogram - a multifactorial risk assessment model for a multifactorial disease. Community Dent Oral Epidemiol, 33, p. 256-264.

[4] Brukiene, V., Aleksejuniene, J., Balciuniene, I. (2005) Dental restorations quality in Lithuanian adolescents. Stomatologija, Baltic Dental and Maxillofacial Journal, 7(4), p. 103-109.

[5] Burke, F.J.T., Lucarotti, P.S.K., Holder, R. (2005) Outcome of direct restorations placed within the general dental services in England and Wales (Part 4): Influence of time and place. Journal of Dentistry, 33, p. 837-847.

[6] Elderton, R.J. (1990) Clinical studies concerning re-restoration of teeth. ADR, 4, p. 4-9. DOI:10.1177/08959374900040010701.

[7] Fedorowicz, Z., Nasser, M., Wilson, N. (2009) Adhesively bonded versus non-bonded amalgam restorations for dental caries (Review). The Cochrane Collaboration, 4, p. 1-10.

[8] Goldberg, A.J. (1990) Deterioration of restorative materiāls and the risk for secondary caries. ADR, 4, p. 14-18. DOI: 10.1177/08959374900040010201.

[9] Gudkina, J, Brinkmane, A. (2008) Caries experience in relation to oral hygiene, salivary cariogenic microflora, buffer capacity and secretion rate in 6-year olds and 12 year olds in Riga. Stomatologija, Baltic Dental and Maxillofacial Journal, 10, p. 76-80.

[10] Henkuzena, I., Care, R., Rogovska, I. (2004) Dental status among 2-6 year old children in Riga city, Latvia. Stomatologija, Baltic Dental and Maxillofacial Journal, 6, p. 28-30.

[11] Hewlett, E.R., Atchison, K.A., White, S.C., Flack, V. (1993) Radiographic secondary caries prevalence in teeth with clinically defective restorations. J Dent Res, 72, p. 1604-1608. DOI: 10. 1177/00220345930720121301. 
Int. Conf. SOCIETY. HEALTH. WELFARE; Congr. of Rehabilitation Doctors of Latvia

[12] Hickel, R., Peschke, A., Tyas, M., Mjör I. (2010) FDI World Dental Federation: clinical criteria for the evaluation of direct and indirect restorations - update and clinical examples. Clinical Oral Investigations, 14(4), p. 349.

[13] Kidd, E.A.M. (1990) Caries diagnosis within restored teeth. ADR, 4, p. 10-13. DOI: $10.1177 / 08959374900040010101$.

[14] Kidd, E.A.M., O'Hara, J.W. (1990) The caries status of occlusal amalgam restorations with marginal defects. J Dent Res, 69, p. 1275-1277. DOI: 10.1177/00220345900690061001.

[15] Kirkevang, L.L., Vaeth, M. (2009) Prevalence and incidence of caries lesions in relation to placement and replacement of fillings: a longitudinal observational radiographic study of an adult Danish population. Caries Res, 43, p. 286-293.

[16] Kroeze, H.J.P., Plasschaert, A.J.M., van’t Hof M.A., Truin, G.J. (1990) Prevalence and need for replacement of amalgam and composite restorations in Dutc adults. J Dent Res, 69, p. 1270-1274. DOI: $10.1177 / 00220345900690060901$.

[17] Kubo, S. (2011) Longevity of resin composite restorations. Japanese Dental Science Review, 47 , p. 43-55.

[18] Mendes, F.M., Braga, M.M., Oliveira, L.B., Antunes, J.L., Ardenghi, T.M., Bönecker, M. (2010) Discriminant validity of the International Caries Detection System (ICDAS) and comparability with World Health Organization criteria in a cross-sectional study. Community Dent Oral Epidemiol, 38, p. 398-407.

[19] Opdam, N.J.M., Bronkhorst, E.M., Cenci, M.S., Huysmans, M.-C. D.N.J.M., Wilson, N.H.F. (2011) Age of failed restorations: A deceptive longevity parameter. Journal of Dentistry, 39, p. 225-230.

[20] Opdam, N.J.M., Loomans, B.A.C., Roeters, F.J.M., Bronkhorst, E.M. (2004) Five-year clinical performance of posterior resin composite restorations placed by dental students. Journal of Dentistry, 32, p. 379-383.

[21] Ozer, L., Thylsstrup, A. (1995) What is known about caries in relation to restorations as a reason for replacement? A Review. ADR, 9, p. 394-402. DOI: 10.1177/08959374950090040901.

[22] Papagiannoulis, L., Kakaboura, A., Eliades, G. (2002) In vivo vs in vitro anticariogenic behavior of glass-ionomer and resin composite restorative materiāls. Dental Materials, 18, p. 561-569.

[23] Pitts, N.B. (2001) Clinical diagnosis of dental caries: a European perspective. J Dent Edu, 65, p. 972-978.

[24] Pitts, N.B. (2009) Introduction. How the detection, assessment, diagnosis and monitoring of caries integrate with personalized caries management. In Pitts, N.B. (ed.), Detection, assessment, diagnosis and monitoring of caries. Monogr Oral Sci. (p. 1-14). Basel, Karger.

[25] Rence-Bambite, I., Berzina, S., Care, R. (2003) Dynamics of Caries Development in Teenagers with High Caries Intensity. RSU Research Articles in Medicine and Pharmacy, p. 416-422.

[26] Riley III, J.L., Gordan, V.V., Rouisse, K.M., McClelland, J., Gilbert, G.H. (2011) Differences in male and female dentist' practice patterns regarding diagnosis and treatment of dental caries. JADA, 142(4), p. 429-440.

[27] Sarrett, D.C. (2005) Clinical challenges and the relevance of materials testing for posterior composite restorations. Dental Materials, 21, p. 9-20.

[28] Scholtanus, J.D., Huysmans, M.-C. D.N.J.M. (2007) Clinical failure of class-II restorations of a highly viscosus glass-ionomer material over 6-year period: A restorative study. Journal of Dentistry, 35, p. 156-162.

[29] Sharif, M.O., Merry, A., Catleugh, M., Tickle, M., Brunton, P., Dunny, S.M., Aggarwal, V.R. (2010) Replacement versus repair of defective restorations in adults: amalgam (Review). The Cochrane Collaboration, 2, p. 1-13.

[30] Silness, J., Löe, H. (1964) Periodontal disease in pregnancy. Correlation between oral hygiene and periodontal condition. Acta Odontol Scand, 22, p. 121-135. 


\section{SHS Web of Conferences}

[31] Söderholm, K.-J.M., Tyas, M.J., Jokstad, A. (1998) Determinants of quality in operative dentistry. CROMB, 9, p. 464-479. DOI: 10.1177/10454411980090040501.

[32] Sunnegårdh-Grönberg, K., Dijken, J.W.V., Funegård, U., Lindberg, A., Nilsson, M. (2009) Selections of dental materiāls and longevity of replaced restorations in Public Dental Health clinics in nothern Sweden. Journal of Dentistry, 37, p. 673-678.

[33] Topping, G.V.A., Pitts, N.B. (2009) Clinical visual caries detection. In Pitts, N.B. (ed.), Detection, assessment, diagnosis and monitoring of caries. Monogr Oral Sci. (p. 15-41). Basel, Karger.

[34] Van Nieuwenhuysen, J.-P., D’Hoore, W., Carvalho, J., Qvist, V. (2003) Long-term evaluation of extensive restorations in permanent teeth. Journal of Dentistry, 31, p. 395-405. 